\section{Kansai science city takes root}

\section{Kyoto} advanced telecommunications research institute, the Kansai region of Japan took its first step towards building a massive $\$ 25,000$ million 'Science City' designed to challenge the Tokyo region's dominance in high technology.

The Kansai region, encompassing Kyoto, Osaka and Kobe, is a powerful force in the world economy. Its gross "national' product is twice that of Australia or the Netherlands, and by 1992 it will have Japan's first 24-hour international airport, providing direct access to foreign capitals.

Tax concessions will encourage research and educational institutes to move to the city. But the intention is to avoid the mistakes made in Japan's last giant science city project at Tsukuba, an hour's ride from Tokyo. Tsukuba was created by relocating 46 government research institutes and two universities from cramped quarters in Tokyo to a undeveloped site. But the city's cultural amenities never caught up with its laboratories and many of its research personnel prefer to commute from Tokyo than to live among the paddy fields.

Kansai's science city is planning for slower and more dispersed growth that will integrate it into surrounding communities. And rather than government laboratories, its focus will be on the development of "the basic sciences and their combination with applied technology". To help towards this objective, an International Institute of Advanced Studies, modelled on those at Princeton and Aspen in the United States, and a new national library, to rival that at the Diet in Tokyo, were planned as early components of the city. The institute will be built alongside

Advanced Telecommunications Research Institute International (better known as just ATR), the first major new laboratory at the city site.

ATR, backed by private industry, the Ministry of International Trade and Industry (MITI) and the Ministry of Posts and Telecommunications, sees little challenge left in developing telecommunications to move information economically from one fixed location to another. Rather, the institute looks to the longterm basic research that will provide automatic translation telephones, totally portable communications systems making it possible to call "anyone, anywhere, at any time", and neural-network computers to provide friendly $\mathrm{man} / \mathrm{machine}$ interfaces. The institute has begun work with 160 researchers and is expected to have 300 by 1995

Two government-supported projects are likely to come to the city: a MITI Institute for Ion Engineering, and a Ministry of Education, Culture and Science (MESC) graduate study institute. The MESC institute will be Japan's second 'graduate university', designed to boost the comparatively low number of postgraduate students in Japan, provide graduate students for the research institutes which are not attached to universities and exercise MESC's newly approved right to accept industrial funding for university chairs.

Private-sector companies will provide the great mass of the research institutes. Land has already been set aside for 10 such institutes. Biotechnology may turn out to be a strong theme, given that more than half of all Japan's major biotechnology and pharmaceutical companies are based in Kansai.

Alun Anderson
WITH the opening last week of a new MICROCHIPS

\section{Britain bows out of hi-tech}

\section{London}

THE sale last week of Britain`s microchip company, Inmos, best-known for its revolutionary transputer, to SGS-Thomson (ST), a semiconductor manufacturer formed by the Italian and French governments in 1987, could mean that Europe has a semiconductor group capable of competing with the world-leaders from Japan and the United States. But the loss of British control illustrates the unwillingness of the country's industry and government to take a longterm view of investment in technology.

Britain's only other microchip manufacturer, Plessey, is also likely to go from national control into the hands of the West German company Siemens and the British company GEC; the takeover is under review by the Monopolies and Mergers
Commission. The British government, after launching Inmos in 1978, sold it six years later, before it made a profit, to the entertainments group Thorn EMI. But Inmos was seen as a high risk for the lighting and television rental group, making profits last year for only the first time since the beginning of the 1980s.

There were fears of redundancies in the three main Inmos plants, which employ over 1000 people, but a spokesman for the company says that ST plans to increase investment in the company, making Britain the headquarters of its microprocessing capability and possibly creating more jobs. For the sale of Inmos, Thorn EMI receives a 10 per cent shareholding in ST, and will continue to obtain the revenue from some patents on Inmos technology.

Christine McGourty

\section{Technology transfer}

THE transfer of technology from universities and national laboratories into industry receives less government support in Britain than in West Germany, France and Japan, despite the relatively low industrial investment in research and development in Britain which makes technology transfer more important, according to a report published last week by Britain's National Economic Development Council. The report compares efforts at technology transfer in Britain, the United States, Japan, France and West Germany. Britain's efforts compare badly with those of its competitiors. The report says that British companies are reluctant to take up external technology and do not view technology as a long-term asset.

C.McG.

\section{Radioactive waste}

THE choice of sites for a deep repository for low-level and intermediate-level radioactive waste in Britain has been narrowed down to two: Sellafield in Cumbria and Dounreay in Caithness. Both are already the sites of nuclear installations. After permission is obtained from the planning authorities, geological investigations will determine which site is chosen. United Kingdom Nirex Limited, which is responsible for the disposal of lowand intermediate-level radioactive waste says each repository could cost about $\$ 3,000$ million and should be in operation by 2005 . C.McG.

\section{Language schism}

ANATOL Sarokin, a geologist with the Byelorussian Hydrogeological Survey, has been threatened with dismissal for insisting on his right to use the Byelorussian language for his field notes and reports. His superiors say that only Russian may be used at work, but Sarokin maintains that as it is a Byelorussian survey, reports should be in Byelorussian particularly at a time when so much emphasis is being publicly put on the fact that the Byelorussian Republic is 'bilingual'. But the directors of the survey say that reports must be in Russian because a copy has to be sent to Moscow, and they cannot afford to have them translated. Sarokin's case has been taken up by the weekly Litaeratura i Mastastva, the main advocate of perestroika in the Byelorussian Republic.

V.R.

\section{Greenpeace recognized}

THE Baltic Marine Environmental Protecion Commission, established in 1980 by the governments of the seven littoral states (Denmark, Sweden, Finland, the Soviet Union, Poland and East Germany and West Germany) has changed its statutes to give observer status to the non-governmental group Greenpeace. At its regular meeting in February, the commission also resolved to set up an early-warning system for incipient environmental disasters; each participating state will warn the others if it observes unusual and disquieting phenomena in the marine environment. V.R. 